\title{
Impact of COVID-19 related unemployment on increased cardiovascular disease in a high-income country: Modeling health loss, cost and equity
}

Authors: Nhung Nghiem, Nick Wilson

Affiliation: Department of Public Health, University of Otago, Wellington 6021

Email: nhung.nghiem@,otago.ac.nz

\begin{abstract}
Background: Cardiovascular disease (CVD) is a leading cause of health loss and health sector economic burdens in high-income countries. Unemployment is associated with increased risk of CVD, and so there is concern that the economic downturn associated with the COVID-19 pandemic will increase the CVD burden.

Aims: This modeling study aimed to quantify health loss, health cost burden and health inequities among people with CVD due to additional unemployment caused by COVID-19 pandemic-related economic disruption in one high-income country: New Zealand (NZ).

Methods: We adapted an established and validated multi-state life-table model for CVD in the national NZ population. We modeled indirect effects (ie, higher CVD incidence due to high unemployment rates) for various scenarios of pandemic-related unemployment projections.

Results: We estimated the CVD-related heath loss in NZ to range from 23,300 to 36,900 HALYs (health-adjusted life years) for the different unemployment scenarios. Health inequities for Māori (Indigenous population) were 3.7 times greater compared to non-Māori (49.9 vs 13.5 HALYs lost per 1000 people).

Conclusions and policy implications: Unemployment due to the COVID-19 pandemic is likely to cause significant health loss and health inequities from CVD in this high-income country. Prevention measures should be considered by governments to reduce this risk, including job creation programs and measures directed towards CVD prevention.
\end{abstract}

Keywords: CVD, unemployment, COVID-19, New Zealand, health inequities, HALYs 


\section{Introduction}

The COVID-19 pandemic had infected 65 million people and caused over 1.5 million deaths globally at the time of writing (early December 2020). ${ }^{(1,2)}$ Unfortunately at this time, pandemic spread was still accelerating and so its final impact before widespread vaccination is used, is likely to be substantially greater.

Globally, this pandemic has disrupted international travel and domestic economies (often via the use of "lockdowns" that depress normal consumer activity and close some workplaces). As such it has depressed gross domestic product (GDP) with this figure for OECD countries being by $-10.5 \%$ in the second quarter in $2020,{ }^{(3)}$ and with an increase in unemployment by an absolute increment of $3.2 \%$ (8.57\% in the second quarter vs $5.35 \%$ in the first quarter $)^{(4)}$ for these countries. ${ }^{(5-7)}$ There is established evidence that economic recessions and depressions can increase poor health. ${ }^{(8,9)}$ This includes cardiovascular disease (CVD) ${ }^{(8-10)}$ as per our recent review of this topic. ${ }^{(11)}$ In particular, one meta-analysis, ${ }^{(9)}$ which included 174,438 participants with a mean follow-up of 9.7 years and 1892 incident cases of CVD from 13 cohort studies, reported that increased job insecurity was associated with increased CVD incidence. Also, there is evidence that people experiencing economic hardship are at higher risk of CVD mortality. ${ }^{(8,9,12)}$ Stress and loneliness (eg, potentially exacerbated by pandemic-related lockdowns) are also known risk factors for CVD onset. ${ }^{(13-15)}$

According to the Global Burden of Disease Study 2017, CVD is still the leading cause of death in the world at an estimated 17.8 million deaths. ${ }^{(16)}$ In New Zealand (NZ), CVD makes up around $14 \%$ of all health loss nationally, and is responsible for a third of the total number of deaths annually. ${ }^{(17)}$ CVD is a particularly important contributor to health loss for the Indigenous Māori population ${ }^{(17,18)}$ and it contributes to health inequities in NZ in terms of both ethnicity and socioeconomic position. ${ }^{(19-21)}$

Although NZ has had a relatively successful health sector response to the COVID-19 pandemic (with an elimination strategy ${ }^{(22)}$ ), the economic impact of the response (via lockdowns, lost revenue from international tourism and international students) has been severe. $^{(23,24)}$

This study therefore aimed to quantify via modeling the health loss, health cost burden and health inequities due to CVD onset as a result of unemployment caused by the COVID-19 pandemic in NZ. $(25,26)$

\section{Methods}

We adapted an established and validated multi-state life-table model for CVD for the national NZ population. ${ }^{(27-29)}$ We modeled only indirect effects (ie, higher CVD incidence due to high unemployment rates) arising from COVID-19 pandemic-related unemployment. Direct effects of the COVID-19 pandemic onto CVD were not considered since the disease burden (only 25 deaths as of 15 December 2020) has been relatively low in NZ prior to the elimination of community transmission. We used various scenarios of the COVID-19 pandemic's impact on unemployment projections in NZ. ${ }^{(23,30)}$ The timeline for the pandemic impact on unemployment was for five years as per the Treasury projections, but a lifetime 
horizon was used for measuring benefits and costs (a five-year horizon was also implemented).

\section{a. Unemployment scenarios due to the COVID-19 pandemic and the response in NZ}

The NZ Government stated that "the COVID-19 pandemic is a 'once in a century' public health shock that is also having a profound impact on economic and financial systems around the world and in NZ." (30) The Government also suggested that the impact of COVID-19 and related response measures on the NZ economy is highly uncertain. So the NZ Treasury presented four different economic scenarios based on health response measures and on key economic assumptions, including the reduction in production output in NZ, the Government's support for households and businesses, and world real production outputs. Detailed scenarios including the baseline unemployment projection before COVID-19, the base case and alternative scenarios (ie, earlier recovery in services exports, extended border controls, and resurgence in community transmission) are presented in Table 1 . The key estimates were that the peak of unemployment rates would vary from $7.7 \%$ in the most relaxed response, to $9 \%$ in the most restrictive one (Table 1). In all of the scenarios, however, the unemployment rates were still higher than that in the baseline scenario (had there never been a pandemic) which was around 4\% after five years (in 2024).

Table 1: Projected unemployment scenarios in NZ as a result of the COVID-19 pandemic and response to it (extracted from a NZ Treasury Report) ${ }^{(23,30)}$

\begin{tabular}{|c|c|c|}
\hline $\begin{array}{l}\text { Scenario } \\
\text { description }\end{array}$ & $\begin{array}{l}\text { Projected unemployment rates } \\
(2020-2024)\end{array}$ & $\begin{array}{l}\text { Assumptions around border restrictions and } \\
\text { exports of services" }\end{array}$ \\
\hline Baseline & $\begin{array}{l}\text { The unemployment rate as per } 2019 \\
(4 \%)\end{array}$ & $\begin{array}{l}\text { Business-as-usual as if there was no COVID-19 } \\
\text { pandemic. }\end{array}$ \\
\hline Base case $^{* *}$ & $\begin{array}{l}\text { The unemployment rate is } 6.9 \% \text { on } \\
\text { average over the forecast period. At the } \\
\text { end of the forecast, the unemployment } \\
\text { rate is } 5.3 \% \text {. }(5.3 * * *, 7.7,7.6,6.6,5.3)\end{array}$ & $\begin{array}{l}\text { Border restrictions are partially eased on July } 2021 \text { and } \\
\text { fully removed on January } 2022 \text {. Real services exports } \\
\text { are } 13 \% \text { lower at the end of the forecasting period than } \\
\text { in the December } 2019 \text { quarter. }\end{array}$ \\
\hline $\begin{array}{l}\text { Earlier } \\
\text { recovery in } \\
\text { exports of } \\
\text { services }\end{array}$ & $\begin{array}{l}\text { The unemployment rate is } 6.2 \% \text { on } \\
\text { average over the forecast period and is } \\
4.8 \% \text { at the end of the forecast. }(5.3 \text {, } \\
7.7,6.4,5.5,4.8)\end{array}$ & $\begin{array}{l}\text { Border restrictions are unchanged from the main } \\
\text { forecast, but exports of services recover more strongly. } \\
\text { Real services exports are } 4 \% \text { lower at the end of the } \\
\text { forecasting period than in the December } 2019 \text { quarter. }\end{array}$ \\
\hline $\begin{array}{l}\text { Extended } \\
\text { border } \\
\text { controls }\end{array}$ & $\begin{array}{l}\text { The unemployment rate is } 7.5 \% \text { on } \\
\text { average over the forecast period and is } \\
6.6 \% \text { at the end of the forecast. } \\
(5.3 * * *, 7.7,8.1,7.6,6.6)\end{array}$ & $\begin{array}{l}\text { Border restrictions are partially eased on July } 2021 \text { but } \\
\text { there is no further substantive easing. Real services } \\
\text { exports are } 35 \% \text { lower at the end of the forecasting } \\
\text { period than in the December } 2019 \text { quarter. }\end{array}$ \\
\hline $\begin{array}{l}\text { Resurgence in } \\
\text { community } \\
\text { transmission }\end{array}$ & $\begin{array}{l}\text { The unemployment rate is } 7.8 \% \text { on } \\
\text { average over the forecast period and is } \\
5.8 \% \text { at the end of the forecast. } \\
(5.3 * * *, 9.0,8.5,7.3,5.8)\end{array}$ & $\begin{array}{l}\text { Border restrictions and real services exports are } \\
\text { unchanged from the main forecast; however, potential } \\
\text { output is } 0.6 \% \text { lower, and real GDP is } 1 \% \text { lower, at the } \\
\text { end of the forecast period. }\end{array}$ \\
\hline
\end{tabular}

Notes:

* Services exports such as international education and international tourism in NZ.

** The base case and alternative scenarios were extracted from Figure 1.20 in an Updated Treasury Report (16 September 2020).

*** Actual unemployment rate in the September quarter in 2020.

\section{b. Calibration of the changes in unemployment rates due to the COVID-19 pandemic by age, sex and ethnicity}


In the NZ Treasury Reports, ${ }^{(23,30)}$ projected unemployment rates were not disaggregated by age, sex and ethnicity. We therefore calibrated the projected changes in unemployment rates annually between 2020-2024, so that it could be used directly in our model as follows.

Data: We averaged the unemployment rates by ethnicity (ie, Māori and non-Māori) over 2010-2014. ${ }^{(31,32)}$ We also averaged the unemployment rates by sex and by age over 20102014. Of note is that these rates were for people aged 15-64 years old in NZ. We used real population by age, sex and ethnicity from Census 2013 to calibrate the unemployment rates. ${ }^{(33)}$

Assumption: We assumed that the relative rate of unemployment rates by age, sex and ethnicity before the COVID-19 pandemic held. That meant that:

(1) $w_{-} e=U_{-} M / U_{-} N M=d U_{-} M / d U_{-} N M$

(2) $w_{-}=U_{-} / U_{-} m=d U_{-} / d U_{-} m$

(3) $w_{-} a 35-44=U_{-} a 35-44 / U_{-} a 45-54=d U_{-} a 35-44 / d U_{-} a 45-54$

Where $U$ is unemployment rate, $d U$ is the absolute change in unemployment rate, $w_{-} e$ is the weight of unemployment rate for Māori over non-Māori, $w_{-}$is the weight of unemployment rate for women over men, and $w_{-}$a35-44 is the weight of unemployment rate for people aged 3544 over the reference age group which is people aged 45-54 years.

Algorithm: From the assumptions in equations (1) to (3), we derived the absolute changes in unemployment rates by ethnicity, sex and 10-year age group, in sequence, as follows:

(4) $d U_{-} M=\left(d U^{*} U_{-} M\right) /\left(p_{0} p_{-} M^{*} U_{-} M+p o p_{-} N M^{*} U_{-} N M\right)$

(5) $d U_{f}=\left(d U^{*} U_{-} f\right) /\left(p_{0} p_{-} f * U_{f}+p o p_{-} m * U_{-} m\right)$

(6) $d U_{-} a 35-44=\left(d U^{*} U_{-} a 35-44\right) /\left(p_{0} p_{-} a 35-44 * U_{-} a 35-44+p_{-} a 45-54 * U_{-} a 45-54+\right.$ pop_a55-64 $* U_{-}$ a55-64+ pop_a15-24 *U_a15-24+ pop_a25-34*U_a25-34)

Where рор $_{-}$is the real Māori population in 2013, рор_a35-44 is the real population aged 3544 years, and so on. Of note is that if any of the assumptions in equations (1)-(3) are altered, the absolute changes derived in equations (4)-(6) are changed accordingly. Furthermore, we assumed sex and age patterns (equations (5)-(6)) followed that for the general population, not by each ethnicity. This involves a slight simplification since there are minor differences in age structure by ethnicity within the studied age-groups, eg, Māori has a younger age group. But as young people have higher unemployment rates, by using the age structure for the general population, our results were conservative towards smaller changes in absolute unemployment rates.

Output: The output of the calibration was absolute changes in unemployment rates (as projected by the Treasury ${ }^{(23,30)}$ ) by ethnicity (Māori/non-Māori), sex and 10-year age group (35-64 years old) for each unemployment scenario annually (2020-2024).

\section{c. Associations between unemployment and, all-cause mortality and CVD incidence}

In this study, we modeled health burdens from pandemic-induced unemployment in terms of CVD morbidity and mortality. We focused on only modeling the impact of unemployment on CVD incidence, and ignored other economic impacts arising from the reduction in real GDP. 
For the impact of unemployment on CVD incidence, we used the results from a large multicountry study by Stuckler et al in 2009. ${ }^{(10)} \mathrm{We}$ considered this work to be the most robust of all the studies we identified in a recent review. ${ }^{(11)}$ This work reported a $0.85 \%$ relative increase in CVD incidence for a $1 \%$ relative increase in the unemployment rate in middleaged men (or a relative risk (RR) of 1.0085 for CVD incidence (including both coronary heart disease [CHD] and stroke)). While Stuckler et al 2009 considered only CVD mortality - for modeling purposes we assumed that this impact was entirely due to increased CVD incidence and not any additional deterioration in CVD case-fatality risk (where we assumed no change in the pre-existing downward trend (Table 3 )). There will be some competing mortality reasons why a $0.85 \%$ increase in incidence doesn't perfectly align with a $0.85 \%$ increase in CVD mortality - and so we reported how the model output actually responds to the $0.85 \%$ incidence increase.

We also assumed that the effect size in CVD incidence increased linearly with an increase in unemployment rate, ie, a $2 \%$ increase in relative unemployment rate translated to $1.7 \%$ relative increase in CVD incidence rate with a RR of 1.0085. The assumption of linearity is the most parsimonious assumption - especially for these relatively small changes. But it is plausible that large increases in unemployment would have normalizing effects and perhaps reduce the impact on CVD (eg, if a large increase in unemployment triggered a disproportionate government response such as a major expansion of welfare provisions).

Table 2 Associations between unemployment and CVD incidence used in this modeling study as per Stuckler et al 2009 (Figure 3) ${ }^{(10)}$

\begin{tabular}{|r|c|l|}
\hline Population group & $\begin{array}{l}\text { Association of a 1\% relative } \\
\text { increase in unemployment on } \\
\text { CVD mortality percentage } \\
\text { changes (\% and (CIs)) as per } \\
\text { Stuckler et al 2009 }\end{array}$ & $\begin{array}{l}\text { Change in annual CVD } \\
\text { incidence (RR(CIs)) } \\
\text { (converted to so as to use in } \\
\text { our modeling work) }\end{array}$ \\
\hline Women, aged 35-44 & $-0.14(-1.95-1.67)$ & $-1.0014(-1.0195-1.0167)$ \\
\hline $45-59$ & $0.10(-1.09-1.30)$ & $1.0010(-1.0109-1.0130)$ \\
\hline $60-64$ & $0.23(-0.22-0.68)$ & $1.0023(-1.0022-1.0068)$ \\
\hline Men, aged 35-44 & $0.85(0.06-1.64)$ & $1.0085(1.0006-1.0164)$ \\
\hline $45-59$ & $0.48(-0.06-1.02)$ & $1.0048(-1.0006-1.0102)$ \\
\hline $60-64$ & $0.38(-0.16-0.91)$ & $1.0038(-1.0016-1.0091)$ \\
\hline
\end{tabular}

\section{d. Key model parameters: epidemiology, economic and unemployment}

We presented all epidemiology and economic key parameters as per the established and validated multi-state life-table $\mathrm{BODE}^{3}$ model for $\mathrm{CVD}$ for the national $\mathrm{NZ}$ population in Table 3. ${ }^{(27-29)}$

We calculated unemployment rates by age, sex and ethnicity used in the BODE ${ }^{3}$ CVD model for each economic scenario listed in Table 1. These were the differences in the projected unemployment rates between the pre-COVID-19 baseline and after the appearance of the COVID-19 pandemic (Baseline Scenario in Table 1). All unemployment rates followed a lognormal distribution with an assumed $20 \%$ standard deviation (due to all health responses and economic outlooks being highly uncertain). 
Of note is that due to the design of the $\mathrm{BODE}^{3} \mathrm{CVD}$ model, we modeled the unemployment impacts due to the COVID-19 pandemic as if they were happening in the 2011-2015 period.

Table 3 Key epidemiology and economic parameters for the established $\mathrm{BODE}^{3} \mathrm{CVD}^{-}$ $\operatorname{model}^{(27-29)}$

\begin{tabular}{|c|c|c|c|}
\hline Parameters & Value & Heterogeneity & Uncertainty \\
\hline $\begin{array}{l}\text { All-cause mortality } \\
\text { and time trends }\end{array}$ & $\begin{array}{l}\text { As per the BODE }{ }^{3} \text { CVD model. }{ }^{(27-29)} \text { Trends for all- } \\
\text { cause mortality were made consistent with long-run } \\
\text { mortality trends for NZ (annual } 2.25 \% \text { mortality } \\
\text { decline for Māori and } 1.75 \% \text { per annum for non- } \\
\text { Māori). Trends were modeled out to } 2026 \text { (ie, for } 15 \\
\text { years), with no subsequent decline for both ethnic } \\
\text { groupings thereafter. }\end{array}$ & $\begin{array}{l}\text { By ethnicity } \\
\text { (Māori/non- } \\
\text { Māori), sex and } \\
\text { age }\end{array}$ & No \\
\hline $\begin{array}{l}\text { Baseline CVD } \\
\text { incidence/morbidity } \\
\text { /mortality and time } \\
\text { trends }\end{array}$ & $\begin{array}{l}\text { As per the BODE } \text { CVD model. }^{(27-29)} \text { As per the NZ } \\
\text { Burden of Disease Study (NZBDS) } \\
\text { continued decline in incidence rates for both CHD and } \\
\text { stroke of } 2.0 \% \text { annually, and also a } 2.0 \% \text { annual } \\
\text { reduction in case fatality so that it reflects improved } \\
\text { treatment and management. }\end{array}$ & $\begin{array}{l}\text { By ethnicity } \\
\text { (Māori/non- } \\
\text { Māori), sex and } \\
\text { age }\end{array}$ & $\begin{array}{l}\text { Uncertainty: } \pm 5 \% \text { SD, } \\
\text { log-normal distribution. }\end{array}$ \\
\hline $\begin{array}{l}\text { Background health } \\
\text { system costs for all } \\
\text { citizens (adjusted } \\
\text { for CHD and stroke } \\
\text { costs) }\end{array}$ & As per $\mathrm{BODE}^{3}$ costing methods ${ }^{(35)}$ & By sex and age & $\begin{array}{l}\text { Uncertainty: } \pm 10 \% \mathrm{SD}, \\
\text { log-normal distribution. }\end{array}$ \\
\hline $\begin{array}{l}\text { Unemployment } \\
\text { duration }\end{array}$ & 5 years as per the NZ Treasury report ${ }^{(23)}$ & No & $\begin{array}{l}\text { No, but we conducted a } \\
\text { sensitivity analysis } \\
\text { whereby unemployment } \\
\text { persists for } 10 \text { years. }\end{array}$ \\
\hline $\begin{array}{l}\text { Unemployment } \\
\text { rates }\end{array}$ & $\begin{array}{l}\text { As per the NZ Treasury's report over 2020-2024 } \\
\text { (Table 1) }\end{array}$ & $\begin{array}{l}\text { By ethnicity } \\
\text { (Māori/non- } \\
\text { Māori), sex and } \\
\text { age }\end{array}$ & $\begin{array}{l}\text { All unemployment rates } \\
\text { followed a log-normal } \\
\text { distribution with an } \\
\text { assumed } 20 \% \text { standard } \\
\text { deviation (due to all } \\
\text { health responses and } \\
\text { economic outlooks being } \\
\text { highly uncertain). }\end{array}$ \\
\hline Discount rate & $\begin{array}{l}3 \% \text { for both health losses and costs as per standard } \\
\text { BODE }^{3} \text { methods }\end{array}$ & No & No \\
\hline Perspective & Health system as per standard $\mathrm{BODE}^{3}$ methods & No & No \\
\hline Time horizon & Lifetime (until died or 110 years old) & No & No \\
\hline
\end{tabular}


medRxiv preprint doi: https://doi.org/10.1101/2020.12.15.20248284; this version posted December 17, 2020. The copyright holder for this preprint (which was not certified by peer review) is the author/funder, who has granted medRxiv a license to display the preprint in perpetuity.

It is made available under a CC-BY-NC-ND 4.0 International license .

\section{Figure 1 Scenarios around the COVID-19 pandemic related additional absolute unemployment rates in 2021 used in the BODE $^{3}$ CVD model by age, sex and ethnicity in $\mathbf{N Z}$}
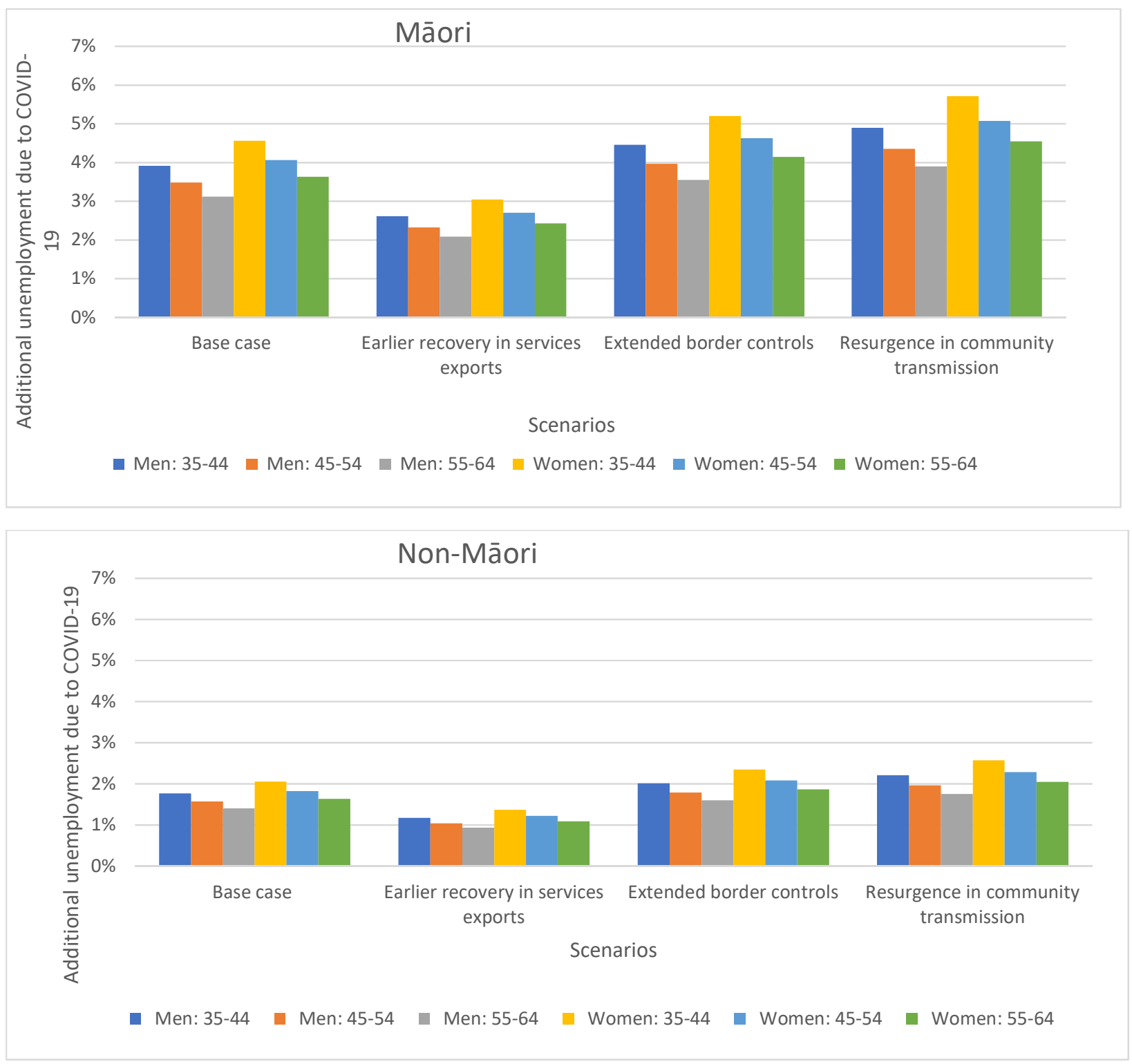

${ }^{a}$ These unemployment rates were the differences in the projected unemployment rates between having the COVID-19 pandemic (Scenarios in Table 1) and had not having the COVID-19 pandemic (Baseline Scenario in Table 1). They were also adjusted by the unemployment rates by age, sex and ethnicity in 2010-2014 reported by the NZ Government.

${ }^{b}$ All unemployment rates followed a log-normal distribution with an assumed 20\% standard deviation (due to all health responses and economic outlooks being highly uncertain).

${ }^{c}$ We only extracted unemployment rates for these age-groups as they are in typical working age age-groups, and are potentially impacted by the CVD burden. But we acknowledge this limitation further in the Discussion.

${ }^{d}$ The age-groups in this Table do not exactly match the ones in Table 2, but we used the closest age group for $R R$ and additional unemployment rate in our model. 
It is made available under a CC-BY-NC-ND 4.0 International license .

Note that in 2021, unemployment rates are similar across scenarios (see Table 1). Furthermore, in the Treasury economic models, the projected unemployment levels take into account the impact from GDP and other services such as impacts from the continued loss of international students and international tourists.

\section{e. Additional scenarios and sensitivity analysis}

Further to four economic scenarios as mentioned above, we also modeled the following sensitivity analyses:

(A) Māori CVD epidemiology parameters as per non-Māori to avoid penalizing Māori due to lower life expectancy and higher comorbidity,

(B) Unemployment persists for longer (ie, 10 years),

(C) No reduction in CVD trend over time (eg, on the assumption that the long-term downward trend in CVD is halted by the obesity epidemic - as seen in some highincome countries). ${ }^{(36)}$

(D) Zero percent discount rate, and

(E) Six percent discount rate.

\section{Results}

Table 4 shows the estimated CVD-related health loss (in HALYs) for the base case (most likely scenario) (3\% discount rate for the remaining life of the NZ population alive in 2011) for various COVID-19 pandemic induced unemployment scenarios (base case, early recovery and extended border control). The health loss for the base-case was estimated at $-30,300$ HALYs (uncertainty interval: $-66,700$ to 4,100$)$. However, only $10 \%$ of the loss $(-3,010$ HALYs) was accumulated in the first five years and more than $50 \%(-17,770$ HALYs $)$ in the 20 years in the future. The estimated CVD-related heath loss in NZ ranged from 23,300 (early recovery in export and services) to 36,900 lost HALYs (resurgence in community transmission) for the different unemployment scenarios. Of which, health loss for Māori ranged between -7,700 HALYs and -13,000, and for non-Māori from -15,700 to -26,600.

For the base case (best-estimate) scenario, health inequities for Māori (Indigenous population) were 3.7 times greater than for non-Māori (49.9 vs 13.5 HALYs lost per 1000 people). Māori men suffered the most health loss per capita (95.9 HALYs per 1000 people); however, the worst inequity impacts between Māori and non-Māori were seen in women aged 45-54 years across all scenarios (six fold difference). Inequities were exacerbated much more than the sum of existing inequities in CVD burden and unemployment, ie, in some groups, the CVD burden for Māori was increased to six times higher than that of non-Māori (compared to a double unemployment rate or CVD burden). The overall pattern of inequity by ethnicity, age and sex was similar among various economic scenarios. 
Table 5 presents the additional health costs incurred to the NZ health system due to the higher CVD burden. The estimates ranged between NZ\$276 million (m) to $458 \mathrm{~m}$ in 2011 value (NZ\$303m to $503 \mathrm{~m}$ or US\$209m to $346 \mathrm{~m}$ in 2019 values) for the various unemployment scenarios. Similar to the health burden, $10 \%$ of the additional health cost was accumulated in the first five years and more than $60 \%$ in the 20 years in the future.

The CVD-related health loss, inequities and health costs were similar in term of relative patterns across scenario analyses and sensitivity analyses (Supplementary Tables 1-5). The equity scenario (Scenario \#A), where Māori CVD epidemiology parameters were assumed to be as per non-Māori, suggested more health loss (up to -13,200 HALYs) and more inequity for Māori population (up to a ratio of Māori/non-Māori HALYs of 7.1). Unemployment persisting for 10 years (\#B) suggested the most health loss (-57,100 HALYs), and 6\% discount rates (\#E) resulted in the smallest health loss $(-18,500$ HALYs). 
Table 4 Health loss (in HALYs) results for the base case (most likely unemployment scenario) (3\% discount rate for the remaining life of the $\mathrm{NZ}$ population alive in 2011) for various COVID-19 pandemic-induced unemployment scenarios from the NZ Treasury

\begin{tabular}{|c|c|c|c|c|c|c|c|c|c|}
\hline \multirow[b]{2}{*}{ Population groups } & \multicolumn{4}{|c|}{ Change in HALYs } & \multicolumn{4}{|c|}{ Change in HALYs per 1000 capita } & $\begin{array}{l}\text { Equity: } \\
\text { Māori/Non-Māori } \\
\text { HALYs per capita }\end{array}$ \\
\hline & 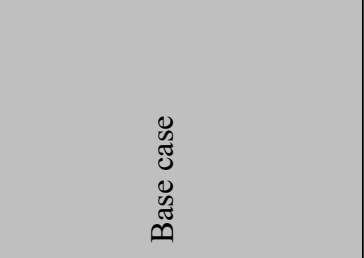 & 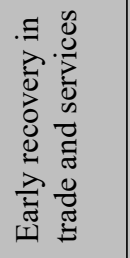 & 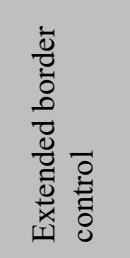 & 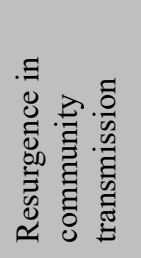 & $\begin{array}{l}0 \\
\tilde{D} \\
0 \\
0 \\
\tilde{D} \\
\tilde{E} \\
\tilde{n}\end{array}$ & 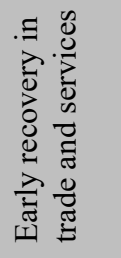 & 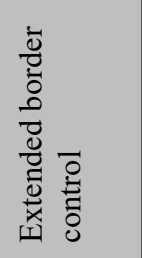 & 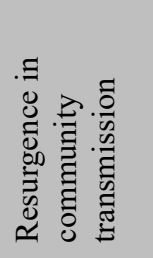 & 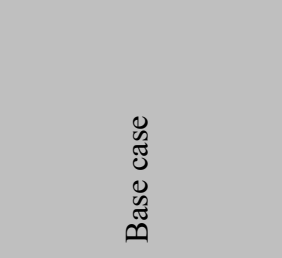 \\
\hline All ethnicity Both sexes All age & $-30,300(-66,700 ; 4,100)$ & $-23,300$ & $-36,900$ & $-39,600$ & -17.7 & -13.6 & -21.5 & -23.1 & $\ldots$ \\
\hline 5 years into future & $-3,010(-6,910 ; 440)$ & $-2,450$ & $-3,440$ & $-3,940$ & -1.8 & -1.4 & -2.0 & -2.3 & $\ldots$ \\
\hline 10 years into future & $-7,950(-17,580 ; 850)$ & $-6,250$ & $-9,430$ & $-10,370$ & -4.6 & -3.6 & -5.5 & -6.0 & $\ldots$ \\
\hline 20 years into future & $-17,770(-38,110 ; 1,520)$ & $-13,800$ & $-21,400$ & $-23,200$ & -10.4 & -8.0 & -12.5 & -13.5 & $\ldots$ \\
\hline Māori Both sexes All age & $-9,910(-24,750 ; 4,730)$ & $-7,700$ & $-12,200$ & $-13,000$ & -49.9 & -38.5 & -61.4 & -65.5 & 3.7 \\
\hline Non-Māori Both sexes All age & $-20,440(-42,040 ; 170)$ & $-15,700$ & $-24,700$ & $-26,600$ & -13.5 & -10.3 & -16.3 & -17.5 & $\ldots$ \\
\hline Māori Men All age & $-8,930(-15,950 ;-2,830)$ & $-6,820$ & $-10,770$ & $-11,540$ & -95.9 & -73.2 & -115.7 & -124.0 & 3.9 \\
\hline Non-Māori Men All age & $-18,170(-32,180 ;-5,220)$ & $-13,900$ & $-21,800$ & $-23,500$ & -24.7 & -18.9 & -29.6 & -31.9 & $\ldots$ \\
\hline Māori Women All age & $-980(-14,640 ; 12,570)$ & -830 & $-1,440$ & $-1,470$ & -9.3 & -7.9 & -13.6 & -13.9 & 3.2 \\
\hline Non-Māori Women All age & $-2,270(-18,600 ; 14,050)$ & $-1,790$ & $-2,900$ & $-3,070$ & -2.9 & -2.3 & -3.7 & -3.9 & $\ldots$ \\
\hline Māori Men 35-44 & $-3,570(-6,850 ;-710)$ & $-2,720$ & $-4,330$ & $-4,630$ & -93.2 & -71.0 & -113.1 & -120.9 & 4.5 \\
\hline Māori Men 45-54 & $-3,490(-7,460 ; 130)$ & $-2,610$ & $-4,270$ & $-4,490$ & -103.3 & -77.4 & -126.3 & -132.8 & 4.0 \\
\hline Māori Men 55-64 & $-1,870(-3,690 ;-190)$ & $-1,480$ & $-2,170$ & $-2,430$ & -89.0 & -70.7 & -103.3 & -115.7 & 3.2 \\
\hline Non-Māori Men 35-44 & $-5,160(-9,860 ;-1,140)$ & $-3,910$ & $-6,260$ & $-6,680$ & -20.7 & -15.7 & -25.1 & -26.8 & $\ldots$ \\
\hline Non-Māori Men 45-54 & $-6,850(-14,810 ; 260)$ & $-5,090$ & $-8,410$ & $-8,810$ & -25.8 & -19.1 & -31.6 & -33.1 & \\
\hline
\end{tabular}




\begin{tabular}{|c|c|c|c|c|c|c|c|c|c|}
\hline \multirow[b]{2}{*}{ Population groups } & \multicolumn{4}{|c|}{ Change in HALYs } & \multicolumn{4}{|c|}{ Change in HALYs per 1000 capita } & $\begin{array}{c}\text { Equity: } \\
\text { Māori/Non-Māori } \\
\text { HALYs per capita }\end{array}$ \\
\hline & 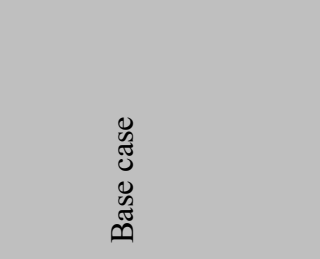 & 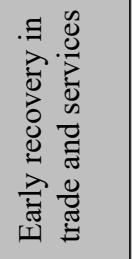 & 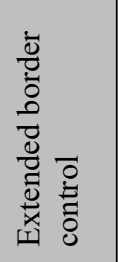 & 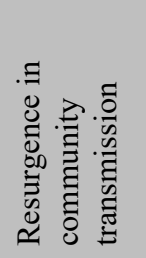 & 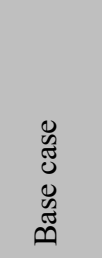 & 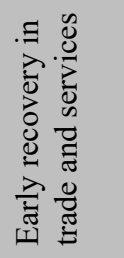 & 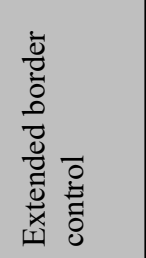 & 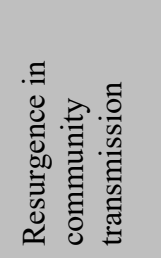 & $\begin{array}{l}\tilde{D} \\
\tilde{\Xi} \\
\tilde{\Xi} \\
\tilde{\Xi} \\
\tilde{\Xi}\end{array}$ \\
\hline Non-Māori Men 55-64 & $-6,160(-12,480 ;-320)$ & $-4,880$ & $-7,130$ & $-8,010$ & -27.8 & -22.1 & -32.2 & -36.2 & $\ldots$ \\
\hline Māori Women 35-44 & $470(-6,100 ; 6,920)$ & 328 & 421 & 512 & 10.7 & 7.4 & 9.5 & 11.6 & 6.9 \\
\hline Māori Women 45-54 & $-610(-8,790 ; 7,570)$ & -514 & -843 & -887 & -16.0 & -13.5 & -22.1 & -23.2 & 6.0 \\
\hline Māori Women 55-64 & $-840(-3,510 ; 1,870)$ & -648 & $-1,018$ & $-1,095$ & -36.2 & -27.9 & -43.9 & -47.2 & 4.3 \\
\hline Non-Māori Women 35-44 & $420(-5,510 ; 6,250)$ & 301 & 384 & 469 & 1.5 & 1.1 & 1.4 & 1.7 & \\
\hline Non-Māori Women 45-54 & $-740(-10,350 ; 8,750)$ & -590 & -985 & $-1,027$ & -2.6 & -2.1 & -3.5 & -3.7 & $\ldots$ \\
\hline Non-Māori Women 55-64 & $-1,940(-7,450 ; 3,520)$ & $-1,500$ & $-2,300$ & $-2,510$ & -8.5 & -6.5 & -10.1 & -11.0 & \\
\hline
\end{tabular}

Notes: *All ages means aged 35-64 years. The equity ratio for Māori/Non-Māori HALYs lost per capita was very similar for all scenarios. 
Table 5 Additional health system costs for the base case (most likely unemployment scenario) (3\% discount rate for the remaining life of the $\mathrm{NZ}$ population alive in 2011)

\begin{tabular}{|c|c|c|c|c|c|c|c|c|}
\hline \multirow[b]{2}{*}{ Groups } & \multicolumn{4}{|c|}{ Additional health system costs (NZS million [m]) } & \multicolumn{4}{|c|}{ Additional health system costs (NZS m) per 1000 capita } \\
\hline & Base case & $\begin{array}{l}\text { Early recovery } \\
\text { in trade and } \\
\text { services }\end{array}$ & $\begin{array}{l}\text { Extended border } \\
\text { control }\end{array}$ & $\begin{array}{l}\text { Resurgence in } \\
\text { community } \\
\text { transmission }\end{array}$ & Base case & $\begin{array}{l}\text { Early } \\
\text { recovery in } \\
\text { trade and } \\
\text { services }\end{array}$ & $\begin{array}{l}\text { Extended } \\
\text { border } \\
\text { control }\end{array}$ & $\begin{array}{l}\text { Resurgence } \\
\text { in } \\
\text { community } \\
\text { transmission }\end{array}$ \\
\hline All ethnicity Both sexes All age & $354(-78 ; 824)$ & 276 & 429 & 458.0 & 0.21 & 0.16 & 0.25 & 0.27 \\
\hline 5 years into future & $234(-6 ; 501)$ & 187 & 276 & 301.0 & 0.14 & 0.11 & 0.16 & 0.18 \\
\hline 10 years into future & $324(-26 ; 703)$ & 254 & 388 & 418.0 & 0.19 & 0.15 & 0.23 & 0.24 \\
\hline 20 years into future & $402(-63 ; 902)$ & 312 & 487 & 520.0 & 0.23 & 0.18 & 0.28 & 0.30 \\
\hline
\end{tabular}




\section{Discussion and conclusions}

\section{a. Main results and interpretation}

In this modeling study, we estimated the CVD-related heath loss in NZ to range from 23,300 to 36,900 HALYs for the different unemployment scenarios. For the base case (best-estimate) scenario, health inequities for Māori were 3.7 times greater. While Māori men suffered the most health loss per capita, the worst inequity impacts between Māori and non-Māori were seen in women aged 45-54 years across all scenarios (six fold difference). Inequities were exacerbated much more than the sum of existing inequities in CVD burden and unemployment, ie, in some groups, Māori's CVD burden was increased to six times higher than that of nonMāori (compared to a double unemployment rate or CVD burden). The additional health costs due to higher CVD burden were also substantial (at NZ\$276m to $458 \mathrm{~m}$ in 2011 values) for the various unemployment scenarios.

\section{b. Study strengths}

Our study has several strengths as follows. First, we used a validated disease model that has been previously applied in the NZ context. Second, we followed economic scenarios projected by the NZ Treasury with valid assumptions on border controls, international tourism and education for NZ. Third, as the COVID-19 pandemic response in NZ was among the strictest ${ }^{(37)}$ and one of the most successful as of December $2020,{ }^{(38)}$ our analysis reflects a pandemic related impact that is relatively independent of the direct disease impacts (ie, it reflects unemployment from the indirect impacts of the NZ response and international impacts impacting on trade). Finally, our study benefited from detailed unemployment data by age, sex and ethnicity in NZ.

\section{c. Study limitations}

We did not consider that all-cause mortality and CVD mortality can also change due to behavioral changes vs supply changes (tobacco, fast food, alcohol, and physical activity level) as a result of the COVID-19 pandemic restrictions. We assumed that the background trend in case fatality risk before the COVID-19 pandemic still held. While it is possible that there is an effect of recessions on poorer health care delivery care (that might increase case fatality risk in those with CVD), in the absence of data we assumed no such additional impact. Also if a recession lowers the affordability of tobacco and alcohol - then there might be non-linear social contagion impacts as whole cohorts of people reduce consumption of these products in social settings (eg, going out less to bars and restaurants). But we had inadequate data on such impacts to consider these in this research. If increased unemployment-induced poverty resulted in less affordable tobacco and less expenditure on junk food (generally more expensive than home-cooked food in $\mathrm{NZ}^{(39)}$ ),- then those factors would tend to reduce CVD. Finally, we ignored people aged 64+ who are in retirement age (although around $20 \%$ of this group are still in formal employment in NZ). 


\section{d. Potential policy implications}

This modeling work suggests that unemployment due to the COVID-19 pandemic is likely to cause significant health loss and health costs from CVD in NZ. Furthermore, this burden exacerbates the health inequities in CVD for Māori due to higher background risks of CVD, and higher unemployment rates. Prevention measures should be considered by central and local governments to reduce this risk, including job creation programs and measures directed towards CVD prevention eg, enhanced progress towards a smokefree country and reducing the hazardous processed food environment as we discuss elsewhere. ${ }^{(11)}$

\section{e. Further research work}

Further work could be done on modeling health inequity, health burden and health cost impacts of COVID-19-related unemployment by occupation. It may also be worth modeling unemployment interventions. Examples could be assuming that a government could implement a job creation package, such as via promoting tourism and education to international visitors and students, so that an absolute $1 \%$ of additional jobs could be created over the period 2020-2024. In addition, a modeled intervention could assume that the NZ Government could target job creation for Māori so that the absolute increases in unemployment rates of Māori were reduced to those of non-Māori. Some of these new jobs could have substantial co-benefits eg, additional tree planting on farmed hill country has benefits in terms of carbon sequestration, enhanced biodiversity, erosion prevention, flood prevention and improved water quality.

To conclude, this modeling work suggests that unemployment due to the COVID-19 pandemic is likely to cause significant health loss, health costs and exacerbate inequities from CVD in this high-income country. Prevention measures should be considered by governments to reduce this risk, including job creation programs and measures directed towards CVD prevention (eg, enhanced progress towards a smokefree country and reducing the hazardous processed food environment). 
Acknowledgement: NN and NW were supported by the Health Research Council of NZ (grant 10/248 and grant 16/443). The authors thank Dr Anja Mizdrak for helpful comments on the design of the study and modeling parameters.

Author contribution: The study was designed by NN and NW. NN, NW led the data collection and parameter specification. NN adapted the CVD version of the model and ran the analyses. NN drafted the manuscript. NW substantially edited and revised the manuscript. All authors approved the final manuscript.

Competing interests: The authors declare no competing interests.

Data availability: Sharing of anonymized cohort data with other researchers or official agencies of the other epidemiological and costing data will generally be possible on request from the authors (pending approval of the relevant official agencies).

Ethics Approval: Approval for use of anonymized administrative data as part of the BODE ${ }^{3}$ Programme has been granted by the Health and Disability Ethics Committees (reference number H13/049). 
Supplementary Table 1 Health loss (in HALYs) results for the Equity scenario (Scenario analysis \#A) (3\% discount rate for the remaining life of the $\mathrm{NZ}$ population alive in 2011) for various unemployment scenarios

\begin{tabular}{|c|c|c|c|c|c|c|c|c|c|}
\hline \multirow[b]{2}{*}{ Groups } & \multicolumn{4}{|c|}{ Change in HALYs } & \multicolumn{4}{|c|}{ Change in HALYs per 1000 capita } & \multirow{2}{*}{ 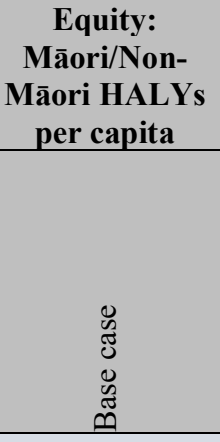 } \\
\hline & $\begin{array}{l}\tilde{D} \\
\tilde{J} \\
\tilde{J} \\
0 \\
\tilde{ే} \\
\tilde{\Xi}\end{array}$ & 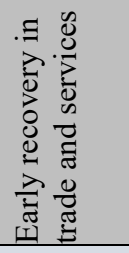 & 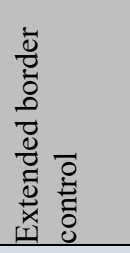 & 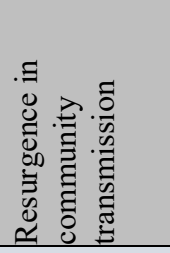 & 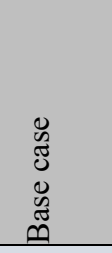 & 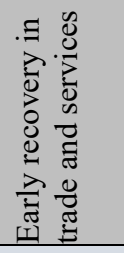 & 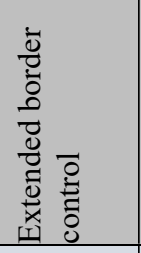 & 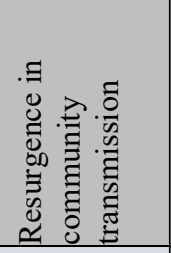 & \\
\hline All ethnicity Both sexes All age & $-31,200$ & $-24,000$ & $-37,900$ & $-40,600$ & -18.2 & -14.0 & -22.1 & -23.7 & $\ldots$ \\
\hline 5 years into future & $-3,030$ & $-2,460$ & $-3,450$ & $-3,960$ & -1.8 & -1.4 & -2.0 & -2.3 & $\ldots$ \\
\hline 10 years into future & $-8,050$ & $-6,320$ & $-9,540$ & $-10,490$ & -4.7 & -3.7 & -5.6 & -6.1 & $\ldots$ \\
\hline 20 years into future & $-18,100$ & $-14,000$ & $-21,800$ & $-23,600$ & -10.6 & -8.2 & -12.7 & -13.8 & $\ldots$ \\
\hline Māori Both sexes All age & $-10,800$ & $-8,300$ & $-13,200$ & $-14,100$ & -54.4 & -41.8 & -66.5 & -71.0 & 4.0 \\
\hline Non-Māori Both sexes All age & $-20,400$ & $-15,700$ & $-24,700$ & $-26,600$ & -13.5 & -10.4 & -16.3 & -17.5 & $\ldots$ \\
\hline Māori Men All age & $-9,630$ & $-7,390$ & $-11,670$ & $-12,510$ & -103.4 & -79.4 & -125.3 & -134.4 & 4.2 \\
\hline Non-Māori Men All age & $-18,000$ & $-13,900$ & $-21,800$ & $-23,500$ & -24.4 & -18.9 & -29.6 & -31.9 & $\ldots$ \\
\hline Māori Women All age & $-1,210$ & -900 & $-1,540$ & $-1,580$ & -11.5 & -8.5 & -14.6 & -15.0 & 3.8 \\
\hline Non-Māori Women All age & $-2,350$ & $-1,790$ & $-2,900$ & $-3,070$ & -3.0 & -2.3 & -3.7 & -3.9 & $\ldots$ \\
\hline Māori Men 35-44 & $-3,820$ & $-2,920$ & $-4,650$ & $-4,970$ & -99.7 & -76.2 & -121.4 & -129.8 & 4.8 \\
\hline Māori Men 45-54 & $-3,760$ & $-2,840$ & $-4,640$ & $-4,880$ & -111.2 & -84.0 & -137.3 & -144.4 & 4.4 \\
\hline Māori Men 55-64 & $-2,050$ & $-1,630$ & $-2,380$ & $-2,660$ & -97.6 & -77.6 & -113.3 & -126.7 & 3.5 \\
\hline Non-Māori Men 35-44 & $-5,130$ & $-3,910$ & $-6,260$ & $-6,680$ & -20.6 & -15.7 & -25.1 & -26.8 & $\ldots$ \\
\hline Non-Māori Men 45-54 & $-6,760$ & $-5,090$ & $-8,410$ & $-8,810$ & -25.4 & -19.1 & -31.6 & -33.1 & $\ldots$ \\
\hline Non-Māori Men 55-64 & $-6,150$ & $-4,880$ & $-7,130$ & $-8,010$ & -27.8 & -22.0 & -32.2 & -36.2 & $\ldots$ \\
\hline Māori Women 35-44 & 417 & 348 & 447 & 543 & 9.5 & 7.9 & 10.1 & 12.3 & 7.1 \\
\hline Māori Women 45-54 & -724 & -547 & -897 & -944 & -19.0 & -14.3 & -23.5 & -24.7 & 6.7 \\
\hline
\end{tabular}




\begin{tabular}{|c|c|c|c|c|c|c|c|c|c|}
\hline \multirow[b]{2}{*}{ Groups } & \multicolumn{4}{|c|}{ Change in HALYs } & \multicolumn{4}{|c|}{ Change in HALYs per 1000 capita } & \multirow{2}{*}{$\begin{array}{c}\text { Equity: } \\
\text { Māori/Non- } \\
\text { Māori HALYs } \\
\text { per capita }\end{array}$} \\
\hline & $\begin{array}{l}0 \\
\tilde{J} \\
\tilde{J} \\
0 \\
\tilde{J} \\
\oplus\end{array}$ & 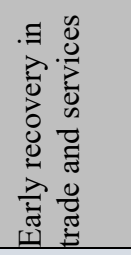 & 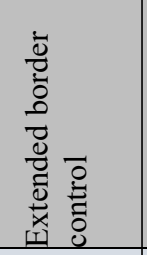 & 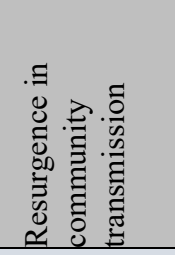 & 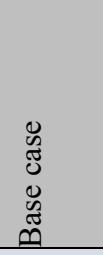 & 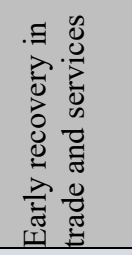 & 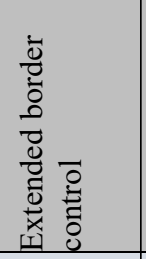 & 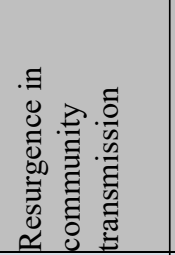 & \\
\hline Māori Women 55-64 & -904 & -696 & $-1,094$ & $-1,177$ & -39.0 & -30.0 & -47.2 & -50.7 & 4.6 \\
\hline Non-Māori Women 35-44 & 361 & 301 & 384 & 469 & 1.3 & 1.1 & 1.4 & 1.7 & \\
\hline Non-Māori Women 45-54 & -788 & -590 & -985 & $-1,027$ & -2.8 & -2.1 & -3.5 & -3.7 & \\
\hline Non-Māori Women 55-64 & $-1,930$ & $-1,500$ & $-2,300$ & $-2,510$ & -8.4 & -6.6 & -10.1 & -11.0 & \\
\hline
\end{tabular}

Notes: All analyses in this table were implemented without uncertainty. Furthermore, please refer to the Additional scenarios and sensitivity analyses in the

Methods section for changes in assumptions compared to the base-case analysis. The equity ratio for Māori/Non-Māori HALYs lost per capita was very similar for all scenarios. 
Supplementary Table 2 Health loss (in HALYs) results for the base case (unemployment persists for 10 years, Scenario analysis \#B) for various unemployment scenarios

\begin{tabular}{|c|c|c|c|c|c|c|c|c|c|}
\hline \multirow[b]{2}{*}{ Groups } & \multicolumn{4}{|c|}{ Change in HALYs } & \multicolumn{4}{|c|}{ Change in HALYs per 1000 capita } & \multirow{2}{*}{ 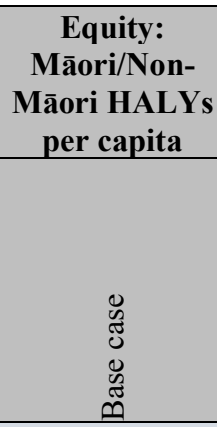 } \\
\hline & 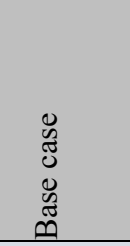 & 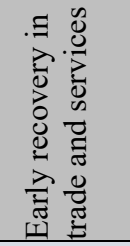 & 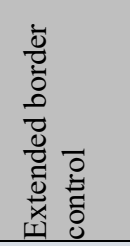 & 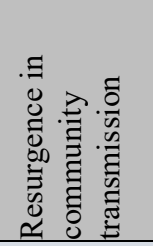 & $\begin{array}{l}\tilde{J} \\
\tilde{J} \\
\tilde{J} \\
\tilde{J} \\
\tilde{\Xi}\end{array}$ & 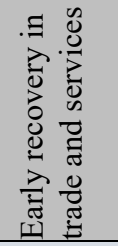 & 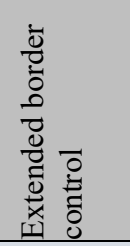 & 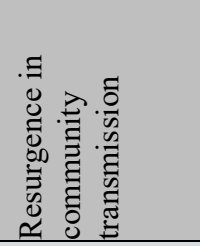 & \\
\hline All ethnicity Both sexes All age & $-57,100$ & $-44,300$ & $-69,100$ & $-73,300$ & -33.3 & -25.8 & -40.3 & -42.7 & $\ldots$ \\
\hline 5 years into future & $-3,100$ & $-2,510$ & $-3,530$ & $-4,040$ & -1.8 & -1.5 & -2.1 & -2.4 & $\ldots$ \\
\hline 10 years into future & $-10,800$ & $-8,470$ & $-12,890$ & $-13,970$ & -6.3 & -4.9 & -7.5 & -8.1 & $\ldots$ \\
\hline 20 years into future & $-29,600$ & $-23,000$ & $-35,800$ & $-38,100$ & -17.3 & -13.4 & -20.9 & -22.2 & $\ldots$ \\
\hline Māori Both sexes All age & $-18,700$ & $-14,500$ & $-22,700$ & $-24,000$ & -94.2 & -73.0 & -114.3 & -120.8 & 3.7 \\
\hline Non-Māori Both sexes All age & $-38,300$ & $-29,800$ & $-46,400$ & $-49,300$ & -25.3 & -19.7 & -30.6 & -32.5 & $\ldots$ \\
\hline Māori Men All age & $-17,260$ & $-13,470$ & $-20,760$ & $-22,090$ & -185.4 & -144.7 & -223.0 & -237.3 & 3.9 \\
\hline Non-Māori Men All age & $-34,900$ & $-27,200$ & $-42,000$ & $-44,800$ & -47.4 & -36.9 & -57.0 & -60.8 & $\ldots$ \\
\hline Māori Women All age & $-1,480$ & $-1,050$ & $-1,980$ & $-1,920$ & -14.0 & -10.0 & -18.8 & -18.2 & 3.2 \\
\hline Non-Māori Women All age & $-3,430$ & $-2,560$ & $-4,350$ & $-4,450$ & -4.4 & -3.3 & -5.6 & -5.7 & $\ldots$ \\
\hline Māori Men 35-44 & $-7,980$ & $-6,260$ & $-9,550$ & $-10,200$ & -208.4 & -163.4 & -249.3 & -266.3 & 4.3 \\
\hline Māori Men 45-54 & $-6,720$ & $-5,180$ & $-8,210$ & $-8,600$ & -198.8 & -153.3 & -242.9 & -254.4 & 3.7 \\
\hline Māori Men 55-64 & $-2,560$ & $-2,030$ & $-2,990$ & $-3,290$ & -121.9 & -96.7 & -142.4 & -156.7 & 3.2 \\
\hline Non-Māori Men 35-44 & $-12,050$ & $-9,430$ & $-14,450$ & $-15,440$ & -48.4 & -37.9 & -58.0 & -62.0 & $\ldots$ \\
\hline Non-Māori Men 45-54 & $-14,350$ & $-11,020$ & $-17,630$ & $-18,430$ & -54.0 & -41.4 & -66.3 & -69.3 & $\ldots$ \\
\hline Non-Māori Men 55-64 & $-8,500$ & $-6,740$ & $-9,940$ & $-10,980$ & -38.4 & -30.4 & -44.9 & -49.6 & $\ldots$ \\
\hline Māori Women 35-44 & 999 & 844 & 1,073 & 1,274 & 22.7 & 19.1 & 24.3 & 28.9 & 7.2 \\
\hline
\end{tabular}




\begin{tabular}{|c|c|c|c|c|c|c|c|c|c|}
\hline \multirow[b]{2}{*}{ Groups } & \multicolumn{4}{|c|}{ Change in HALYs } & \multicolumn{4}{|c|}{ Change in HALYs per 1000 capita } & \multirow{2}{*}{$\begin{array}{c}\text { Equity: } \\
\text { Māori/Non- } \\
\text { Māori HALYs } \\
\text { per capita }\end{array}$} \\
\hline & 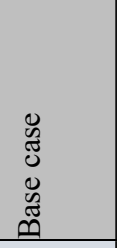 & 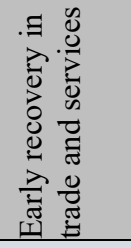 & 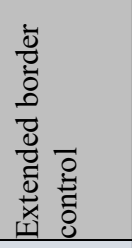 & 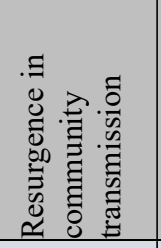 & 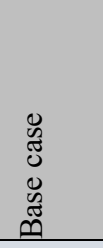 & 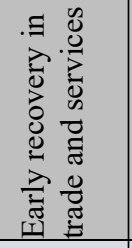 & 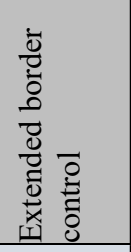 & 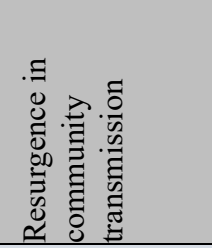 & \\
\hline Māori Women 45-54 & $-1,378$ & $-1,058$ & $-1,690$ & $-1,771$ & -36.1 & -27.7 & -44.2 & -46.4 & 5.6 \\
\hline Māori Women 55-64 & $-1,098$ & -834 & $-1,358$ & $-1,424$ & -47.3 & -35.9 & -58.5 & -61.4 & 4.3 \\
\hline Non-Māori Women 35-44 & 853 & 726 & 905 & 1,088 & 3.1 & 2.7 & 3.3 & 4.0 & \\
\hline Non-Māori Women 45-54 & $-1,798$ & $-1,379$ & $-2,214$ & $-2,311$ & -6.4 & -4.9 & -7.9 & -8.3 & \\
\hline Non-Māori Women 55-64 & $-2,490$ & $-1,900$ & $-3,040$ & $-3,230$ & -10.9 & -8.3 & -13.3 & -14.1 & \\
\hline
\end{tabular}

Notes: All analyses in this table were implemented without uncertainty. Furthermore, please refer to the Additional scenarios and sensitivity analyses in the

Methods section for changes in assumptions compared to the base-case analysis. The equity ratio for Māori/Non-Māori HALYs lost per capita was very similar for all scenarios. 
Supplementary Table 3 Health loss (in HALYs) results for the base case (CVD incidence trend level-off, Scenario analysis \#C) for various unemployment scenarios

\begin{tabular}{|c|c|c|c|c|c|c|c|c|c|}
\hline \multirow[b]{2}{*}{ Groups } & \multicolumn{4}{|c|}{ Change in HALYs } & \multicolumn{4}{|c|}{ Change in HALYs per 1000 capita } & \multirow{2}{*}{ 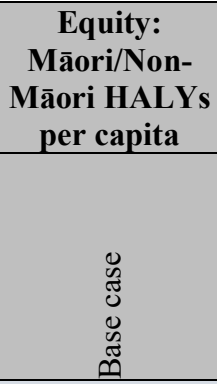 } \\
\hline & $\begin{array}{l}0 \\
\tilde{\Xi} \\
\tilde{J} \\
0 \\
\tilde{\Xi} \\
\tilde{\Xi}\end{array}$ & 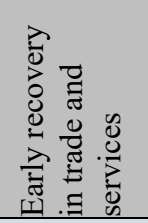 & 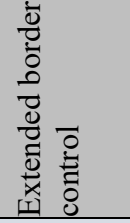 & 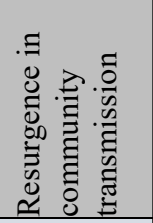 & $\begin{array}{l}0 \\
\tilde{\Xi} \\
\tilde{J} \\
0 \\
\tilde{\Xi} \\
\tilde{\Xi}\end{array}$ & 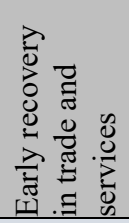 & 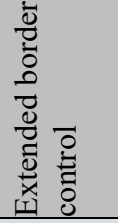 & 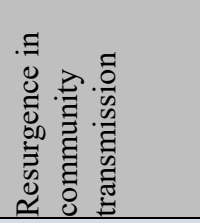 & \\
\hline All ethnicity Both sexes All age & $-31,200$ & $-23,800$ & $-38,000$ & $-40,600$ & -18.2 & -13.9 & -22.2 & -23.7 & $\ldots$ \\
\hline 5 years into future & $-3,120$ & $-2,530$ & $-3,570$ & $-4,070$ & -1.8 & -1.5 & -2.1 & -2.4 & $\ldots$ \\
\hline 10 years into future & $-8,250$ & $-6,460$ & $-9,820$ & $-10,750$ & -4.8 & -3.8 & -5.7 & -6.3 & $\ldots$ \\
\hline 20 years into future & $-18,400$ & $-14,200$ & $-22,200$ & $-23,900$ & -10.7 & -8.3 & -12.9 & -13.9 & $\ldots$ \\
\hline Māori Both sexes All age & $-10,300$ & $-7,800$ & $-12,600$ & $-13,400$ & -51.9 & -39.3 & -63.4 & -67.5 & 3.8 \\
\hline Non-Māori Both sexes All age & $-20,900$ & $-16,000$ & $-25,400$ & $-27,200$ & -13.8 & -10.6 & -16.7 & -17.9 & $\ldots$ \\
\hline Māori Men All age & $-9,130$ & $-6,990$ & $-11,120$ & $-11,870$ & -98.1 & -75.1 & -119.4 & -127.5 & 3.9 \\
\hline Non-Māori Men All age & $-18,500$ & $-14,200$ & $-22,400$ & $-24,000$ & -25.1 & -19.3 & -30.4 & -32.6 & $\ldots$ \\
\hline Māori Women All age & $-1,160$ & -860 & $-1,490$ & $-1,520$ & -11.0 & -8.2 & -14.1 & -14.4 & 3.5 \\
\hline Non-Māori Women All age & $-2,420$ & $-1,830$ & $-2,990$ & $-3,150$ & -3.1 & -2.3 & -3.8 & -4.0 & $\ldots$ \\
\hline Māori Men 35-44 & $-3,670$ & $-2,800$ & $-4,490$ & $-4,780$ & -95.8 & -73.1 & -117.2 & -124.8 & 4.5 \\
\hline Māori Men 45-54 & $-3,550$ & $-2,680$ & $-4,410$ & $-4,620$ & -105.0 & -79.3 & -130.5 & -136.7 & 4.0 \\
\hline Māori Men 55-64 & $-1,910$ & $-1,510$ & $-2,220$ & $-2,480$ & -91.0 & -71.9 & -105.7 & -118.1 & 3.2 \\
\hline Non-Māori Men 35-44 & $-5,280$ & $-4,010$ & $-6,470$ & $-6,870$ & -21.2 & -16.1 & -26.0 & -27.6 & $\ldots$ \\
\hline Non-Māori Men 45-54 & $-6,930$ & $-5,200$ & $-8,670$ & $-9,030$ & -26.1 & -19.6 & -32.6 & -34.0 & $\ldots$ \\
\hline Non-Māori Men 55-64 & $-6,260$ & $-4,950$ & $-7,270$ & $-8,140$ & -28.3 & -22.4 & -32.8 & -36.8 & $\ldots$ \\
\hline Māori Women 35-44 & 404 & 336 & 433 & 525 & 9.2 & 7.6 & 9.8 & 11.9 & 6.7 \\
\hline
\end{tabular}




\begin{tabular}{|c|c|c|c|c|c|c|c|c|c|}
\hline \multirow[b]{2}{*}{ Groups } & \multicolumn{4}{|c|}{ Change in HALYs } & \multicolumn{4}{|c|}{ Change in HALYs per 1000 capita } & \multirow{2}{*}{$\begin{array}{c}\text { Equity: } \\
\text { Māori/Non- } \\
\text { Māori HALYs } \\
\text { per capita }\end{array}$} \\
\hline & $\begin{array}{l}0 \\
\tilde{J} \\
\tilde{J} \\
\mathscr{J} \\
\tilde{\oplus}\end{array}$ & 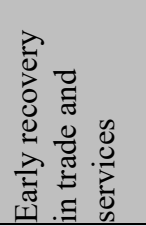 & 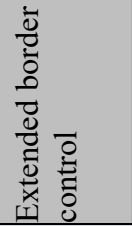 & 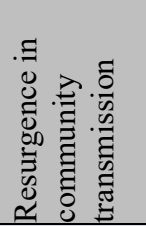 & 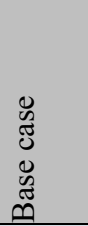 & 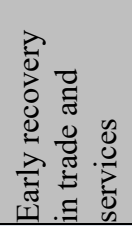 & 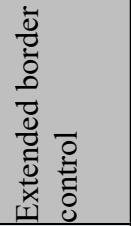 & 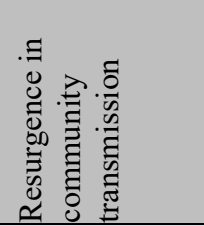 & \\
\hline Māori Women 45-54 & -702 & -529 & -874 & -915 & -18.4 & -13.8 & -22.9 & -24.0 & 6.3 \\
\hline Māori Women 55-64 & -865 & -664 & $-1,051$ & $-1,127$ & -37.3 & -28.6 & -45.3 & -48.6 & 4.3 \\
\hline Non-Māori Women 35-44 & 369 & 308 & 394 & 480 & 1.4 & 1.1 & 1.4 & 1.8 & \\
\hline Non-Māori Women 45-54 & -812 & -606 & $-1,020$ & $-1,058$ & -2.9 & -2.2 & -3.6 & -3.8 & \\
\hline Non-Māori Women 55-64 & $-1,970$ & $-1,530$ & $-2,360$ & $-2,570$ & -8.6 & -6.7 & -10.3 & -11.2 & \\
\hline
\end{tabular}

Notes: All analyses in this table were implemented without uncertainty. Furthermore, please refer to the Additional scenarios and sensitivity analyses in the

Methods section for changes in assumptions compared to the base-case analysis. The equity ratio for Māori/Non-Māori HALYs lost per capita was very similar for all scenarios. 
Supplementary Table 4 Health loss (in HALYs) results for the base case (0\% discount rate, Sensitivity analysis \#D) for various unemployment scenarios

\begin{tabular}{|c|c|c|c|c|c|c|c|c|c|}
\hline \multirow[b]{2}{*}{ Groups } & \multicolumn{4}{|c|}{ Change in HALYs } & \multicolumn{4}{|c|}{ Change in HALYs per 1000 capita } & \multirow{2}{*}{$\begin{array}{c}\text { Equity: } \\
\text { Māori/Non- } \\
\text { Māori HALYs } \\
\text { per capita } \\
\\
\\
\delta \\
\tilde{ల} \\
\delta \\
\tilde{ల} \\
\tilde{D} \\
\end{array}$} \\
\hline & $\begin{array}{l}\tilde{J} \\
\tilde{J} \\
\tilde{\Xi} \\
\tilde{\Xi} \\
\tilde{\Xi}\end{array}$ & 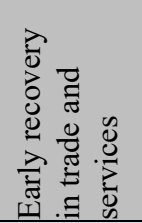 & 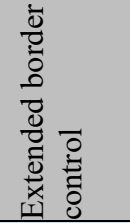 & 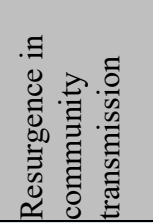 & $\begin{array}{l}\tilde{J} \\
\tilde{J} \\
\tilde{J} \\
\tilde{\Xi} \\
\tilde{\Xi}\end{array}$ & 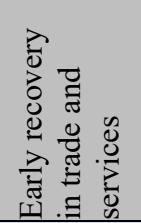 & 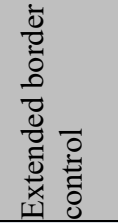 & 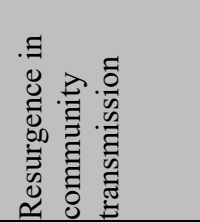 & \\
\hline All ethnicity Both sexes All age & $-56,200$ & $-42,800$ & $-68,700$ & $-73,100$ & -32.8 & -25.0 & -40.1 & -42.6 & \\
\hline 5 years into future & $-3,270$ & $-2,650$ & $-3,730$ & $-4,260$ & -1.9 & -1.5 & -2.2 & -2.5 & $\ldots$ \\
\hline 10 years into future & $-9,380$ & $-7,340$ & $-11,140$ & $-12,220$ & -5.5 & -4.3 & -6.5 & -7.1 & $\ldots$ \\
\hline 20 years into future & $-24,600$ & $-19,000$ & $-29,700$ & $-32,000$ & -14.3 & -11.1 & -17.3 & -18.7 & $\ldots$ \\
\hline Māori Both sexes All age & $-17,900$ & $-13,600$ & $-22,000$ & $-23,300$ & -90.1 & -68.5 & -110.8 & -117.3 & 3.6 \\
\hline Non-Māori Both sexes All age & $-38,300$ & $-29,200$ & $-46,700$ & $-49,800$ & -25.3 & -19.3 & -30.8 & -32.8 & $\ldots$ \\
\hline Māori Men All age & $-16,000$ & $-12,220$ & $-19,510$ & $-20,790$ & -171.9 & -131.3 & -209.6 & -223.3 & 3.7 \\
\hline Non-Māori Men All age & $-34,100$ & $-26,100$ & $-41,500$ & $-44,500$ & -46.3 & -35.4 & -56.4 & -60.4 & $\ldots$ \\
\hline Māori Women All age & $-1,900$ & $-1,390$ & $-2,450$ & $-2,470$ & -18.0 & -13.2 & -23.2 & -23.4 & 3.4 \\
\hline Non-Māori Women All age & $-4,140$ & $-3,110$ & $-5,150$ & $-5,390$ & -5.3 & -4.0 & -6.6 & -6.9 & $\ldots$ \\
\hline Māori Men 35-44 & $-6,950$ & $-5,290$ & $-8,500$ & $-9,030$ & -181.5 & -138.1 & -221.9 & -235.8 & 4.1 \\
\hline Māori Men 45-54 & $-6,080$ & $-4,590$ & $-7,550$ & $-7,900$ & -179.9 & -135.8 & -223.4 & -233.7 & 3.7 \\
\hline Māori Men 55-64 & $-2,970$ & $-2,340$ & $-3,460$ & $-3,850$ & -141.4 & -111.4 & -164.8 & -183.3 & 3.0 \\
\hline Non-Māori Men 35-44 & $-10,890$ & $-8,270$ & $-13,350$ & $-14,180$ & -43.7 & -33.2 & -53.6 & -56.9 & $\ldots$ \\
\hline Non-Māori Men 45-54 & $-12,870$ & $-9,650$ & $-16,090$ & $-16,760$ & -48.4 & -36.3 & -60.5 & -63.0 & $\ldots$ \\
\hline Non-Māori Men 55-64 & $-10,380$ & $-8,210$ & $-12,090$ & $-13,510$ & -46.9 & -37.1 & -54.6 & -61.0 & $\ldots$ \\
\hline Māori Women 35-44 & 747 & 621 & 799 & 972 & 16.9 & 14.1 & 18.1 & 22.0 & 6.0 \\
\hline Māori Women 45-54 & $-1,265$ & -952 & $-1,573$ & $-1,648$ & -33.1 & -24.9 & -41.2 & -43.1 & 5.9 \\
\hline Māori Women 55-64 & $-1,379$ & $-1,055$ & $-1,680$ & $-1,795$ & -59.4 & -45.5 & -72.4 & -77.4 & 4.1 \\
\hline
\end{tabular}




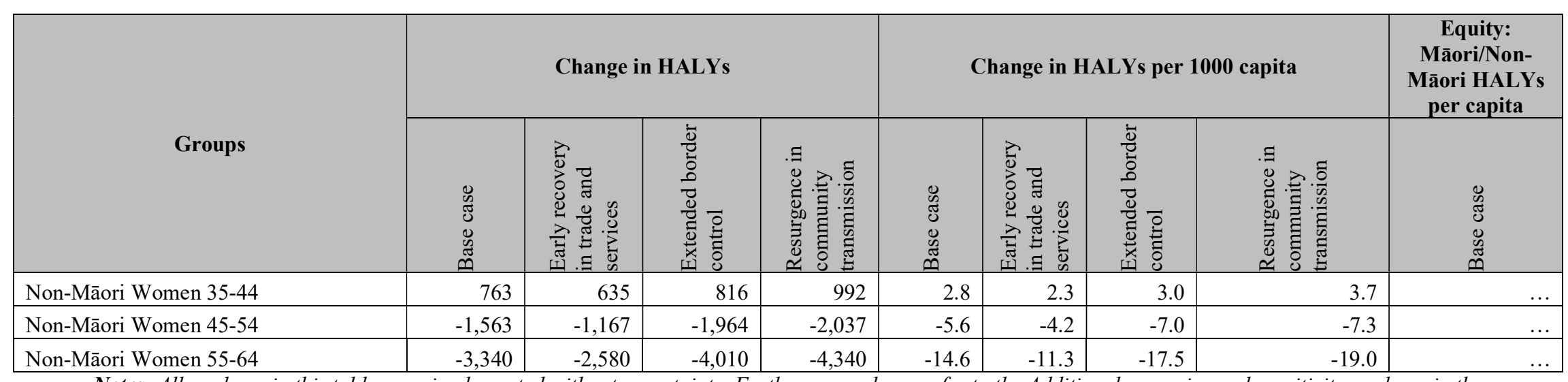

Notes: All analyses in this table were implemented without uncertainty. Furthermore, please refer to the Additional scenarios and sensitivity analyses in the

Methods section for changes in assumptions compared to the base-case analysis. The equity ratio for Māori/Non-Māori HALYs lost per capita was very similar for all scenarios. 
Supplementary Table 5 Health loss (in HALYs) results for the base case (6\% discount rate, Sensitivity analysis \#E) for various unemployment scenarios

\begin{tabular}{|c|c|c|c|c|c|c|c|c|c|}
\hline \multirow[b]{2}{*}{ Groups } & \multicolumn{4}{|c|}{ Change in HALYs } & \multicolumn{4}{|c|}{ Change in HALYs per 1000 capita } & \multirow{2}{*}{$\begin{array}{c}\text { Equity: } \\
\text { Māori/Non- } \\
\text { Māori HALYs } \\
\text { per capita } \\
\end{array}$} \\
\hline & $\begin{array}{l}0 \\
\mathbb{E} \\
\tilde{J} \\
0 \\
\tilde{~} \\
\tilde{D}\end{array}$ & 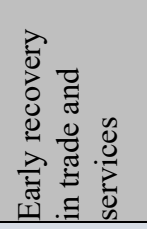 & 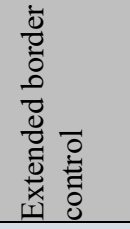 & 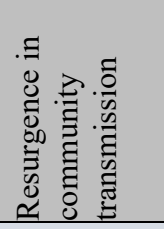 & $\begin{array}{l}0 \\
\tilde{\Xi} \\
\tilde{J} \\
0 \\
\tilde{\Xi} \\
\mathscr{\Xi} \\
\end{array}$ & 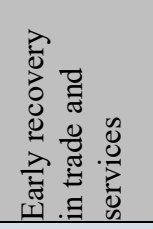 & 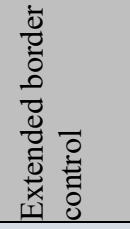 & 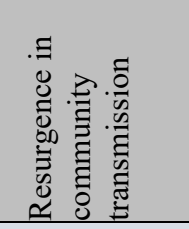 & \\
\hline All ethnicity Both sexes All age & $-18,500$ & $-14,300$ & $-22,300$ & $-24,100$ & -10.8 & -8.3 & -13.0 & -14.1 & \\
\hline 5 years into future & $-2,790$ & $-2,270$ & $-3,170$ & $-3,640$ & -1.6 & -1.3 & -1.8 & -2.1 & $\ldots$ \\
\hline 10 years into future & $-6,800$ & $-5,350$ & $-8,030$ & $-8,860$ & -4.0 & -3.1 & -4.7 & -5.2 & $\ldots$ \\
\hline 20 years into future & $-13,200$ & $-10,300$ & $-15,900$ & $-17,200$ & -7.7 & -6.0 & -9.3 & -10.0 & ... \\
\hline Māori Both sexes All age & $-6,200$ & $-4,800$ & $-7,500$ & $-8,100$ & -31.2 & -24.2 & -37.8 & -40.8 & 3.8 \\
\hline Non-Māori Both sexes All age & $-12,300$ & $-9,500$ & $-14,800$ & $-16,000$ & -8.1 & -6.3 & -9.8 & -10.6 & ... \\
\hline Māori Men All age & $-5,500$ & $-4,250$ & $-6,630$ & $-7,150$ & -59.1 & -45.6 & -71.2 & -76.8 & 4.0 \\
\hline Non-Māori Men All age & $-10,800$ & $-8,400$ & $-13,000$ & $-14,100$ & -14.7 & -11.4 & -17.7 & -19.1 & $\ldots$ \\
\hline Māori Women All age & -720 & -540 & -910 & -940 & -6.8 & -5.1 & -8.6 & -8.9 & 3.6 \\
\hline Non-Māori Women All age & $-1,460$ & $-1,120$ & $-1,780$ & $-1,910$ & -1.9 & -1.4 & -2.3 & -2.4 & $\ldots$ \\
\hline Māori Men 35-44 & $-2,090$ & $-1,600$ & $-2,520$ & $-2,710$ & -54.6 & -41.8 & -65.8 & -70.8 & 4.8 \\
\hline Māori Men 45-54 & $-2,160$ & $-1,640$ & $-2,650$ & $-2,800$ & -63.9 & -48.5 & -78.4 & -82.8 & 4.3 \\
\hline Māori Men 55-64 & $-1,260$ & $-1,010$ & $-1,460$ & $-1,640$ & -60.0 & -48.1 & -69.5 & -78.1 & 3.4 \\
\hline Non-Māori Men 35-44 & $-2,860$ & $-2,190$ & $-3,460$ & $-3,720$ & -11.5 & -8.8 & -13.9 & -14.9 & $\ldots$ \\
\hline Non-Māori Men 45-54 & $-3,990$ & $-3,020$ & $-4,940$ & $-5,200$ & -15.0 & -11.4 & -18.6 & -19.6 & $\ldots$ \\
\hline Non-Māori Men 55-64 & $-3,960$ & $-3,160$ & $-4,570$ & $-5,150$ & -17.9 & -14.3 & -20.6 & -23.3 & $\ldots$ \\
\hline Māori Women 35-44 & 240 & 200 & 257 & 312 & 5.4 & 4.5 & 5.8 & 7.1 & 7.1 \\
\hline Māori Women 45-54 & -409 & -311 & -504 & -534 & -10.7 & -8.1 & -13.2 & -14.0 & 6.6 \\
\hline
\end{tabular}




\begin{tabular}{|c|c|c|c|c|c|c|c|c|c|}
\hline \multirow[b]{2}{*}{ Groups } & \multicolumn{4}{|c|}{ Change in HALYs } & \multicolumn{4}{|c|}{ Change in HALYs per 1000 capita } & \multirow{2}{*}{$\begin{array}{c}\text { Equity: } \\
\text { Māori/Non- } \\
\text { Māori HALYs } \\
\text { per capita }\end{array}$} \\
\hline & 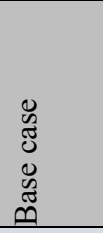 & 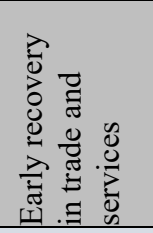 & 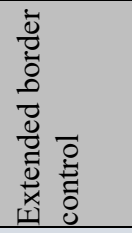 & 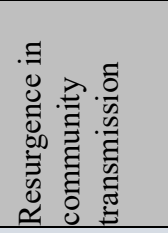 & $\begin{array}{l}0 \\
\tilde{J} \\
\tilde{J} \\
\tilde{\Xi} \\
\ddot{ص}\end{array}$ & 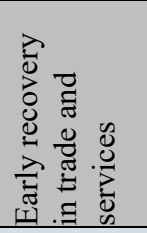 & 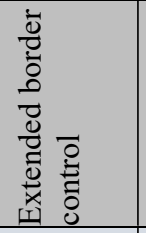 & 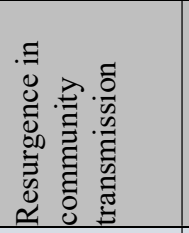 & \\
\hline Māori Women 55-64 & -553 & -429 & -665 & -720 & -23.8 & -18.5 & -28.7 & -31.0 & 4.5 \\
\hline Non-Māori Women 35-44 & 209 & 174 & 223 & 271 & 0.8 & 0.6 & 0.8 & 1.0 & $\ldots$ \\
\hline Non-Māori Women 45-54 & -455 & -342 & -565 & -592 & -1.6 & -1.2 & -2.0 & -2.1 & $\ldots$ \\
\hline Non-Māori Women 55-64 & $-1,220$ & -950 & $-1,440$ & $-1,580$ & -5.3 & -4.2 & -6.3 & -6.9 & \\
\hline
\end{tabular}

Notes: All analyses in this table were implemented without uncertainty. Furthermore, please refer to the Additional scenarios and sensitivity analyses in the

Methods section for changes in assumptions compared to the base-case analysis. The equity ratio for Māori/Non-Māori HALYs lost per capita was very similar for all scenarios. 


\section{References}

1. Ruan S. Likelihood of survival of coronavirus disease 2019. The Lancet Infectious Diseases. 2020;20(6):630-1.

2. Johns Hopkins University. COVID-19 Dashboard by the Center for Systems Science and Engineering (CSSE) at Johns Hopkins University Johns Hopkins University 2020 [Available from:

https://gisanddata.maps.arcgis.com/apps/opsdashboard/index.html\#/bda7594740fd402994234 67b48e9ecf6.

3. OECD. G20 GDP Growth - Second quarter of 2020, OECD 2020 [cited 20203 Dec]. Available from: http://www.oecd.org/sdd/na/g20-gdp-growth-second-quarter-2020oecd.htm\#: :text=GDP $\% 20$ contracted $\% 20 \mathrm{by} \% 20$ an $\% 20$ average,to $\% 20 \mathrm{be} \% 20$ more $\% 20$ wide ly $\% 20$ felt.\&text $=$ Year\%2Don $\% 2$ Dyear\%20GDP\%20in, 1.7\%25\%20in $\% 20$ the $\% 20$ previous $\%$ 20quarter.

4. OECD. Unemployment rate 2020 [cited 20203 Dec]. Available from: https://data.oecd.org/unemp/unemployment-rate.htm.

5. Ozili PK, Arun T. Spillover of COVID-19: impact on the Global Economy. Available at SSRN 3562570. 2020.

6. Maliszewska M, Mattoo A, Van Der Mensbrugghe D. The Potential Impact of COVID-19 on GDP and Trade: A Preliminary Assessment. World Bank Policy Research Working Paper. 2020(9211).

7. Fernandes N. Economic effects of coronavirus outbreak (COVID-19) on the world economy. Available at SSRN 3557504. 2020.

8. Roelfs DJ, Shor E, Davidson KW, Schwartz JE. Losing life and livelihood: A systematic review and meta-analysis of unemployment and all-cause mortality. Social Science \& Medicine. 2011;72(6):840-54.

9. Virtanen M, Nyberg ST, Batty GD, Jokela M, Heikkilä K, Fransson EI, et al. Perceived job insecurity as a risk factor for incident coronary heart disease: systematic review and meta-analysis. British Medical Journal. 2013;347:f4746.

10. Stuckler D, Basu S, Suhrcke M, Coutts A, McKee M. The public health effect of economic crises and alternative policy responses in Europe: an empirical analysis. The Lancet. 2009;374(9686):315-23.

11. Nghiem N, Mizdrak A, Wilson N. Increased unemployment from the COVID-19 pandemic, what might be the adverse impacts on cardiovascular disease in Aotearoa/New Zealand and how might this be prevented? N Z Med J. 2020;133(1526):89-98.

12. Hughes A, Kumari M, McMunn A, Bartley M. Unemployment and inflammatory markers in England, Wales and Scotland, 1998-2012: Meta-analysis of results from 12 studies. Brain, behavior, and immunity. 2017;64:91-102.

13. Steptoe A, Kivimäki M. Stress and cardiovascular disease. Nature Reviews Cardiology. 2012;9(6):360.

14. Steptoe A, Kivimäki M. Stress and cardiovascular disease: an update on current knowledge. Annual review of public health. 2013;34:337-54.

15. Thurston RC, Kubzansky LD. Women, loneliness, and incident coronary heart disease. Psychosomatic medicine. 2009;71(8):836.

16. Wang H, Naghavi M, Allen C, Barber RM, Bhutta ZA, Carter A, et al. Global, regional, and national life expectancy, all-cause mortality, and cause-specific mortality for 249 causes of death, 1980-2015: a systematic analysis for the Global Burden of Disease Study 2015. The lancet. 2016;388(10053):1459-544. 
17. Ministry of Health. Health loss in New Zealand: A report from the New Zealand Burden of Diseases, Injuries and Risk Factors Study, 2006-2016. Wellington: Ministry of Health; 2013.

18. Grey C, Jackson R, Wells S, Wu B, Poppe K, Harwood M, et al. Trends in ischaemic heart disease: patterns of hospitalisation and mortality rates differ by ethnicity (ANZACS-QI 21). The New Zealand Medical Journal (Online). 2018;131(1478):21-31.

19. Chan WC, Wright C, Riddell T, Wells S, Kerr AJ, Gala G, et al. Ethnic and socioeconomic disparities in the prevalence of cardiovascular disease in New Zealand. N Z Med J. 2008;121(1285):11-20.

20. Blakely T, Disney G, Atkinson J, Teng A, Mackenbach JP. A typology for charting socioeconomic mortality gradients:" Go south-west". Epidemiology. 2017.

21. Disney G, Teng A, Atkinson J, Wilson N, Blakely T. Changing ethnic inequalities in mortality in New Zealand over 30 years: linked cohort studies with 68.9 million person-years of follow-up. Population Health Metrics. 2017;15(1):15.

22. Baker MG, Wilson N, Anglemyer A. Successful elimination of Covid-19 transmission in New Zealand. N Engl J Med 2020;(7 August) doi:101056/NEJMc2025203

https://wwwnejmorg/doi/101056/NEJMc2025203?url_ver=Z3988-

$2003 \&$ rfr $\_$id $=$ori:rid:crossreforg\&rfr dat $=$cr_pub\%20\%200pubmed. 2020.

23. The Treasury. Pre-election Economic and Fiscal Update 2020. Online: The Treasury; 2020 [cited 20206 Nov]. Available from: https://www.treasury.govt.nz/publications/efu/preelection-economic-and-fiscal-update-2020.

24. Statistics New Zealand. Unemployment rate hits 5.3 percent due to COVID-19:

StatsNZ; 2020 [cited 20206 Nov]. Available from:

https://www.stats.govt.nz/news/unemployment-rate-hits-5-3-percent-due-to-covid-19.

25. Ministry of Health. Potential Worse Case Health Impacts from the COVID-19

Pandemic for New Zealand if Eradication Fails: Report to the NZ Ministry of Health

https://www.health.govt.nz/system/files/documents/publications/report for chief science ad visor - health - 24 march final.pdf. Wellington; 2020.

26. Ministry of Health. Supporting the COVID-19 pandemic response:Surveillance and Outbreak Analytics

https://www.health.govt.nz/system/files/documents/publications/report for_moh_covid19 surveillance outbreak analytics final.pdf. Wellington; 2020.

27. Nghiem N, Blakely T, Cobiac LJ, Cleghorn CL, Wilson N. The health gains and cost savings of dietary salt reduction interventions, with equity and age distributional aspects. BMC Public Health. 2016;16(1):423.

28. Nghiem N, Blakely T, Cobiac LJ, Pearson AL, Wilson N. Health and economic impacts of eight different dietary salt reduction interventions. PLoS ONE. 2015;10(4).

29. Nghiem N, Knight J, Mizdrak A, Blakely T, Wilson N. Preventive Pharmacotherapy for Cardiovascular Disease: A Modelling Study Considering Health Gain, Costs, and CostEffectiveness when Stratifying by Absolute Risk. Scientific Reports. 2019;9(1):19562. 30. The Treasury. Treasury Report T2020/973: Economic scenarios - 13 April 2020, https://treasury.govt.nz/publications/tr/treasury-report-t2020-973-economic-scenarios-13april-2020. Wellington: The Treasurey; 2020.

31. Statistics New Zealand. Introducing ethnic labour force statistics by age 2013 [Available from: http://infoshare.stats.govt.nz/browse for stats/income-andwork/employment and unemployment/ethnic-labour-force-stats-by-age.aspx\#gsc.tab=0. 32. Ministry of Social Development. The Social Report 20162016 [cited 202024 Nov]. Available from: http://socialreport.msd.govt.nz/documents/2016/msd-the-social-report2016.pdf. 
33. Statistics New Zealand. 2013 Census 2013 [cited 202024 Nov]. Available from: http://infoshare.stats.govt.nz/Census/2013-census.aspx\#gsc.tab=0.

34. Ministry of Health. Ways and Means: A report on methodology from the New Zealand Burden of Disease, Injury and Risk Study, 2006 - 2016. Wellington: Ministry of Health. http://www.health.govt.nz/publication/ways-and-means-report-methodology-newzealand-burden-disease-injury-and-risk-study-2006-2016; 2013.

35. Blakely T, Kvizhinadze G, Atkinson J, Dieleman J, Clarke P. Health system costs for individual and comorbid noncommunicable diseases: An analysis of publicly funded health events from New Zealand. PLoS Medicine. 2019;16(1):e1002716.

36. GBD 2017 Causes of Death Collaborators. Global, regional, and national age-sexspecific mortality for 282 causes of death in 195 countries and territories, 1980-2017: a systematic analysis for the Global Burden of Disease Study 2017. Lancet. 2018;392(10159):1736-88.

37. Hale T, Webster S, Petherick A, Phillips T, Kira B. Oxford COVID-19 Government Response Tracker. Blavatnik School of Government. 2020; https://covidtracker.bsg.ox.ac.uk/. 38. Wilson N, Grout L, Summers J, Nghiem N, Baker M. Health and Economic Impacts of the COVID-19 Response: NZ Compared to OECD Countries [Internet]. Wellington: University of Otago. 2020. [cited 2020]. Available from: https://blogs.otago.ac.nz/pubhealthexpert/?p=8818\#more-8818. 39. Mackay S, Vandevijvere S, Xie P, Lee A, Swinburn B. Paying for convenience: comparing the cost of takeaway meals with their healthier home-cooked counterparts in New Zealand. Public Health Nutr. 2017;20(13):2269-76. 